\title{
Agensia Penyebab Vibriosis Pada Udang Vaname (Litopenaus gariepinus) yang Dibudidayakan Secara Intensif Di Kendal
}

\author{
Sarjito, M. Apriliani, D.Afriani, dan A.H. Condro Haditomo \\ Jurusan Perikanan, Fakultas Perikanan dan IImu Kelautan Universitas Diponegoro \\ JI. Prof. Soedarto, SH. Kampus UNDIP Tembalang, Semarang 50275 \\ Email : sarjito_msdp@yahoo.com
}

\begin{abstract}
Budidaya udang vaname (Litopenaus gariepinus) secara intensif telah dilakukan di kabupaten Kendal, sebagai upaya peningkatan produksi. Salah satu kendala yang sering terjadi pada budidaya udang intensif adalah serangan penyakit bakteri, termasuk pula vibriosis. Penelitian ini bertujuan untuk mengkaji keanekaragaman bakteri yang berasosiasi dengan udang yang terserang vibriosis secara intensif beserta gejala klinisnya. Udangvaname yang menunjukkan gejala vibriosis diperoleh dari pertambakan intensif di kabupaten Demak. Sebanyak 22 isolat bakteri (SMC 01 - SSD 10) berhasil diisolasi dari hepatopacreas udangvaname pada mediumThiosulfate Citrate Bile Salts Sucrose (TCBS). Berdasarkan perfomance morphologi dari keua puluh dua isolat (bentuk, warna dan karakter koloni) dipilih 5 isolat ( SMC 01,SMC 04, SSD 01, SSD 03, dan SSD 07) untuk uji selanjutnya yaitu karakterisasi secara morfologi dan uji biokimia. Uji sensitivitas terhadap antibiotik yang beredar hanya dilakukan pada 3 isolat terpilih(SMC 01, SMC 04, dan SSD 03). Gejala klinis udang yang terserang vibriosis adalah : tubuh (carapace) memerah, melanosis pada kulit, nekrosis pada ekor, kaki renang dan kaki jalan memerah serta hepatopankreas yang memerah cenderung gelap. Hasil karakterisasi dengan pendekatan secara morfologi dan biokimia diperoleh pula bahwa bakteri yang berasosiasi dengan udangvaname (L. gariepinus) dari tambak intensif kabupaten Kendal adalah Vibrio vulnificus (SMC 01), V. mimicus (SMC 04), V.damsella (SSD 01), V. parahaemolytics ( SSD 03), V. fluvialis (SSD 07). Hasil Uji sensitivitas menunjukkan bahwa ketiga isolat terpilih (SMC 01, SMC 04, dan SSD 03) tidak sensitif terhadap beberapa antibiotik.
\end{abstract}

Kata kunci: vibriosis, sensitifitas, salinitas, udangvaname.

\section{PENDAHULUAN}

Udangraname, Litopenaus vannamei, merupakan salah satu komoditas unggulan perikanan. Produksi total udang nasional pada tahun 2014 mencapai 592.219 ton, dengan komoditas udang vaname sebesar $70 \%$, udang windu $21 \%$ dan udang jenis lain 9\%. (KKP, 2014). Permintaan yang terus meningkat, baik pasar lokal dan domestik, maka mendorong pembudidaya udanguntuk meningkatkan produksi dengan menerapkan teknologi intensifikasi. Budidayaudang secara intensif telah dilakukan di beberapa spot pertambakan pantai utara Jawa Tengah, antara lain: pertambakan Kabupaten Kendal. Akan tetapi, pengaplikasian budidaya intensif secara tidak tepat dan bijaksana akan dapat menimbulkan dampak negatif, seperti munculnya serangan penyakit. Serangan penyakit ini dapat terjadi, karena interaksi yang tidak serasi antara lingkungan, biota dan agensia penyebab penyakit (Irianto, 2005). Penyakit pada udang disebabkan oleh parasit, virus dan bakteri (Lighter, 1997). Salah satu penyakit bakteri pada udang adalah vibriosis (Austin dan Austin, 2007; Sarjito et al., 2012). Penyakit ini disebabkan oleh serangan bakteri Genus Vibrio (Austin and Austin, 200).Penyakit ini telah menjadi masalah dalam kegiatan budidaya udang laut, air payau (Irianto, 2005) dan air tawar (Austin dan Austin, 2007; Sharma dan Chaturvedi, 2007). Vibriosis pernah dilaporkan telah menyerang kerapu (Sarjito et al., 2007; 
Sarjito et al., 2009); udang windu (Sarjito et al., 2012), dn akibat dari serangan penyakit in menyebabkan kematian organisme yang dibudidayakan (Smith, 2006; Austin dan Austin, 2007).

Berbagai agensia penyebab vibriosis pada udang/ikan telah dilaporkan oleh Austin dan Austin (2007); Noorlis et al., (2011); Sarjito et al., (2009); Sarjito et al.(2012). Menurut Austin dan Austin (2007), agensia penyebab vibriosis pada udang/invertebrate adalah Vibrio alginolyticus, $V$. damsela, $V$. charchariae, V.anguilarum, $V$. ordalli, V.cholerae, V. salmonicida, V. vulnificus, V. parahaemolyticus, V. pelagia, V. splendida, $\checkmark$. fischeri dan V.harveyi (Austin dan Austin, 2007). V. alginolyticus dilaporkan menginfeksi udang kakap merah (Noorlis et al. (2011). V. anguillarum menginfeksi sidat, udang, dan rainbow trout (Schaperclaus, 1992).V. parahaemolyticus dan $V$. harveyi ditemukan pada ikan kerapu (Sarjito et al.,2009).

Agensia penyebab vibriosisdapat bersifat pathogen, menyebar dengan cepat pada budidaya sistem intensif, sehingga mampu menyebabkan mortalitas hingga mencapai 85 \% Guzma et al. (2001) Oleh karena itu, serangan penyakit ini merupakan permasalahan yang cukup serius bagi udang di tambak intensif Untuk itu, dalam penelitian ini, selain menentukan bakteri agensiapenyebab vibriosis pada udangudang yang dibudidayakan secara intensif dan jugamenentukan sensitivitasselektif agensia penyebab vibriosis terhadap antibiotik yang diperbolehkan yang beredar.

\section{MATERI DAN METODE}

Metode yang dilakukan pada penelitian ini adalah eksploratif konfirmatory (Nazir, 1999). Sebanyak 20 sampel udangsakit diperoleh dari pertambakan intensif di kabupaten Kendal. Udang sampel dipilih secara selektif, dilihat dari gejala klinis yang terlihat mengacu pada Sarjito et al. (2012). Isolasi dan purifikasi bakteri dilakukan denganmetode streakpada mediaTCBS (Brock
danMadigan, 1991; Sarjito et al., 2007) di Laboratorium Terpadu universitas Diponegoro. Dua puluh duaisolat murni (SMC 01 - SDC10)diperoleh dari hepatopankreas udang sampel, kemudian disimpan pada media Nutrien Agar Trisalt (NA, Merck) miring.Berdasarkan perfomance morphologi ((bentuk, warna dan karakter koloni) dari kedua puluh duaisolat terpilih lima isolat SMC 01, SMC 04, SSD 01, SSD 03, dan SSD 07 untuk karakterisasi. Sedangkan untuk uji sensitivitas hanya dilakukan pada tiga isolat yaitu isolat SMC 01, SMC 04, dan SSD 03.Kelima isolat terpilih dikultur pada media cair Zobelt (Sarjito, 2010). Karakterisasi kelima isolat terpilih dilakukan secara morfologi dan biokimia mengacu pada Macfaddin (1980) dan Sarjito et al. (2007). Selanjutnyaidentifikasi bakteri dilakukan berdasarkan Bergey's Manual of Determinative Bacteriology (Holt et al. 1998) dan Bacterial Fish Pathogens: Disease in Farmed and Wild Fish (Austin dan Austin 2007). Test ini dilakukan di Stasiun Karantina Ikan, Pengendalian Mutu dan Keamanan Hasil Perikanan (SKIPM), Kelas I Yogyakarta.

Uji sensitivitas tiga selektif isolat (SMC 01; SMC 03 dan SSD 03) terhadap tigaantibiotik (eritromisin, enrofloksasin dan oksitetrasiklin) dilakukan secara in vitro, menggunakan petri dish sesuai dengan metoda Holstrom et al. (2003). Dosis yang digunakan untuk uji sensitvitas ini adalah $6 \mu$ $8 \mu$ dan $10 \mu$ untuk obat $A^{\text {TM }}$, dan $2,5 \mu, 5 \mu$ dan $7,5 \mu$ untuk antibiotikeritromisin, enrofloksasin dan oksitetrasiklin. Pengukuran zona hambat menggunakan jangka sorong di sekitar kertas cakram setiap 24 jam, sampai zona bening tersebut ditumbuhi bakteri.Inkubasi dilakukan pada suhu ruangan selama 48 jam. Hasil sensitivitas ini mengacu pada ketentuan National Commitee for Clinical Laboratorium Standard (NCCLS) (2001).

\section{HASIL DAN PEMBAHASAN}

Gejala klinis yang terdeteksi pada udang sampel yang terserangvibriosis adalah tubuh (carapace) memerah, melanosis pada kulit, nekrosis pada ekor, kaki renang dan kaki jalan memerah serta 
hepatopankreas yang memerah cenderung gelap.Hasil isolasi dari ketigapuluhudang sampel diperoleh 22 isolat bakteri (Tabel 1.)

Berdasarkan karakter morfologi(bentuk, warna dan karakter koloni)dari 22 isolat,dipilih 5 isolat untuk dilakukan uji selanjutnya (Tabel 2).

Hasil karakterisasi secara morfologi dan biokimia dari kelima bakteri agensia penyebab vibriosis pada udangvaname yang dibudidayakan secara intensif dari kabupaten Kendal disajikan pada Tabel 4.

Hasil karekterisasi kelima bakteri yang berasosiasi dengan udang yang terserang vibriosis adalah Vibrio vulnificus (SMC 01), V. mimicus (SMC 04), V.damsella (SSD 01), V. parahaemolytics ( SSD 03), V. fluvialis(SSD 07).Hasil uji sensitivitasketiga selektif agensia penyebab vibriosis (SMC 01, SMC 04 dan SSD 03) terhadap berbagai antibiotik eritromisin, enrofloksasin dan oksitetrasiklindisajikan pada Tabel 5.

Tabel 1. Karakter Isolat Berdasarkan Kode Isolat, Asal Isolat, Warna Koloni, Bentuk Koloni, serta Karakteristik pada Media TCBS

\begin{tabular}{lllllll}
\hline No & Kode & Asal Isolat & $\begin{array}{l}\text { Warna } \\
\text { Koloni }\end{array}$ & $\begin{array}{l}\text { Bentuk } \\
\text { Koloni }\end{array}$ & Karakteristik Koloni \\
\hline 1. & SMC01 & Hepatopankreas & Kuning & Bulat & Halus & Cekung \\
2.. & SMC 02 & Hepatopankreas & Hijau & Bulat & Halus & Cembung \\
3. & SMC03 & Hepatopankreas & Putih & Bulat & Halus & Datar \\
4. & SMC04 & Hepatopankreas & Putih & Bulat & Halus & Datar \\
5. & SMC05 & Hepatopankreas & Kuning & Bulat & Halus & Cekung \\
6. & SMC06 & Hepatopankreas & Hijau & Bulat & Halus & Cembung \\
7. & SMC 07 & Hepatopankreas & Hijau & Bulat & Halus & Cembung \\
8. & SMC08 & Hepatopankreas & Hijau & Bulat & Halus & Cembung \\
9. & SMC09 & Hepatopankreas & Hijau & Bulat & Halus & Cembung \\
10 & SMC 10 & Hepatopankreas & Hijau & Bulat & Halus & Cembung \\
11 & SMC 11 & Hepatopankreas & Putih & Bulat & Halus & Cembung \\
12. & SMC 12 & Hepatopankreas & Hijau & Bulat & Halus & Cembung \\
13. & SSD 01 & Hepatopankreas & hitam & Bulat & Halus & Cembung \\
14. & SSD 02 & Hepatopankreas & hijau & Bulat & Halus & Cembung \\
15. & SSD 03 & Hepatopankreas & hijau & Bulat & Halus & Cembung \\
16. & SSD 04 & Hepatopankreas & hijau & Bulat & Halus & Cembung \\
17. & SSD05 & Hepatopankreas & Hijau & Bulat & Halus & Cembung \\
18. & SSD 06 & Hepatopankreas & kuning & Bulat & Halus & Cembung \\
19. & SSD 07 & Hepatopankreas & kuning & Bulat & Halus & Cembung \\
20. & SSD 08 & Hepatopankreas & kuning & Bulat & Halus & Cembung \\
21. & SSD 09 & Hepatopankreas & kuning & Bulat & Halus & Cembung \\
22. & SSD 10 & Hepatopankreas & kuning & Bulat & Halus & Cembung \\
\hline
\end{tabular}

Tabel 2. Limalsolat Terpilih Berdasarkan Asal dan Perfomance Morfology

\begin{tabular}{|c|c|c|c|c|c|c|}
\hline No. & $\begin{array}{l}\text { Kode } \\
\text { isolat }\end{array}$ & Asal Isolat & $\begin{array}{l}\text { Warna } \\
\text { Koloni }\end{array}$ & $\begin{array}{l}\text { Bentuk } \\
\text { Koloni }\end{array}$ & Bentuk Tepi & $\begin{array}{c}\text { Karakteristik } \\
\text { Koloni }\end{array}$ \\
\hline 1. & SCM 01 & Hepatopankreas & Kuning & Bulat & Halus & Cekung \\
\hline 2. & SMC 04 & Hepatopankreas & Putih & Bulat & Halus & Datar \\
\hline 3. & SSD 01 & hepatopankreas & hitam & bulat & Halus & Cembung \\
\hline 4. & SSD03 & hepatopankreas & hijau & bulat & Halus & Cekung \\
\hline 5. & SSD 07 & hepatopankreas & kuning & bulat & Halus & Cembung \\
\hline
\end{tabular}


Tabel 4. Hasil Uji Morfologi dan Biokimia Isolat SMC 01, SMC 04, SSD 01 , SSD 03 dan SSD 07

\begin{tabular}{|c|c|c|c|c|c|}
\hline \multirow{3}{*}{ Uji Bio Kimia } & \multicolumn{5}{|c|}{ Kode Isolat bakteri } \\
\hline & SMC 01 & SMC 04 & SSD 01 & SSD 03 & SSD 07 \\
\hline & $\begin{array}{c}\text { Vibrio } \\
\text { vulnivicus }\end{array}$ & $\begin{array}{c}\text { Vibrio } \\
\text { mimicus }\end{array}$ & $\begin{array}{c}\text { Vibrio } \\
\text { damsela }\end{array}$ & $\begin{array}{c}\text { Vibrio } \\
\text { parahaemolyticus }\end{array}$ & $\begin{array}{l}\text { Vibrio } \\
\text { fluvialis }\end{array}$ \\
\hline \multicolumn{6}{|l|}{ Morfologi bentuk } \\
\hline Bentuk koloni & Circular & Circular & Circular & Circular & Circular \\
\hline Bentuk elevasi & Convex & Even & Concave & Convex & Concave \\
\hline Bentuk tepi & Entrie & Entrie & Entrie & Entrie & Rough \\
\hline Warna & Kuning & Kuning & Putih & Putih & Kuning \\
\hline \multirow[t]{2}{*}{ Media/warna } & TCBS/ & TCBS/ & TCBS/ & TCBS/ & TCBS/ \\
\hline & Kuning & Putih & Hitam & Putih & Kuning \\
\hline \multicolumn{6}{|l|}{ Morfologi sel } \\
\hline Gram & - & - & - & - & - \\
\hline Bentuk & Batang & Batang & Batang & Batang & Batang \\
\hline $0 \% \mathrm{NaCl}$ & + & + & + & + & + \\
\hline \multirow{2}{*}{\multicolumn{6}{|c|}{$\begin{array}{l}5 \% \mathrm{NaCl} \\
\text { Sifat fisiologis dan } \\
\text { biokimia }\end{array}$}} \\
\hline & & & & & \\
\hline $\mathrm{O} / \mathrm{F}$ & $\mathrm{F}$ & $\mathrm{F}$ & $\mathrm{F}$ & $\mathrm{F}$ & $\mathrm{F}$ \\
\hline Motility & + & + & + & + & + \\
\hline \multicolumn{6}{|l|}{ Produksi : } \\
\hline Katalase & + & + & + & + & + \\
\hline Oksidase & + & + & + & + & + \\
\hline $\mathrm{H}_{2} \mathrm{~S}$ & - & + & - & + & - \\
\hline \multirow{2}{*}{$\begin{array}{l}\text { Lisin } \\
\text { dekarboksilase }\end{array}$} & + & + & V & + & - \\
\hline & & & & & \\
\hline \multirow{2}{*}{ Ornithin } & + & + & - & + & - \\
\hline & \multicolumn{5}{|c|}{ dekarboksilase } \\
\hline TSIA & $\mathrm{A} / \mathrm{A}$ & $\mathrm{A} / \mathrm{K}$ & $A / A$ & $\mathrm{~A} / \mathrm{K}$ & $\mathrm{A} / \mathrm{A}$ \\
\hline Tumbuh pada $30^{\circ} \mathrm{C}$ & + & + & + & + & + \\
\hline Indole & + & + & - & + & + \\
\hline Metyl-red & + & + & + & + & - \\
\hline Voges-proskaeur & - & - & - & - & + \\
\hline Simon citrat & $\mathrm{A} / \mathrm{A}$ & $\mathrm{A} / \mathrm{A}$ & + & - & $+S$ \\
\hline Pemecahan gelatin & & & & & \\
\hline & + & + & + & + & + \\
\hline Urea & - & - & - & - & + \\
\hline Hidrolisis dari : & & & & & \\
\hline Aesculin & + & + & + & - & - \\
\hline Produksi asam dari : & & & & & \\
\hline Glukosa, acid & + & + & + & - & - \\
\hline Lactos, acid & + & - & - & - & + \\
\hline Sukrosa, acid & + & - & - & - & + \\
\hline Xylose & - & - & - & - & - \\
\hline $\begin{array}{r}\text { Keterangan: } \\
\text { ND } \\
\vee\end{array}$ & $\begin{array}{l}\text { :90\% lebih s } \\
\text { : not detern } \\
\text { : variabel }\end{array}$ & $e^{\text {in positif }}$ & $\begin{array}{l}-: 90 \% \text { le } \\
d: 11-89\end{array}$ & $\begin{array}{l}\text { in strain negatif } \\
\text { positif }\end{array}$ & \\
\hline
\end{tabular}


Tabel 5. Uji Sensitivitas Antibiotik Eritromisin, Enrofloksasin, dan Oksitetrasiklin Pada Ketiga Selektif Agensia Penyebab Vibriosis pada Udang Vaname

\begin{tabular}{|c|c|c|c|c|c|c|c|c|c|c|c|c|c|c|c|c|c|}
\hline \multirow{5}{*}{$\begin{array}{l}\text { Kode } \\
\text { Isolat }\end{array}$} & \multicolumn{5}{|c|}{$\begin{array}{c}\text { Antibiotik } \\
\text { (A) }\end{array}$} & \multicolumn{6}{|c|}{$\begin{array}{l}\text { Antibiotik } \\
\text { (B) }\end{array}$} & \multicolumn{6}{|c|}{$\begin{array}{l}\text { Antibiotik } \\
\text { (C) }\end{array}$} \\
\hline & \multicolumn{17}{|c|}{ Waktu (Jam) } \\
\hline & & 24 & & & 48 & & & 24 & & & 48 & & & 24 & & & 48 \\
\hline & \multicolumn{17}{|c|}{ Dosis $(\mu \mathrm{l})$} \\
\hline & 6 & 8 & 10 & 6 & 8 & 10 & 2,5 & 5 & 7,5 & 2,5 & 5 & 7,5 & 2,5 & 5 & 7,5 & 2,5 & 5 \\
\hline SMC 01 & $R$ & $R$ & $\mathrm{R}$ & $R$ & $\mathrm{R}$ & $\mathrm{R}$ & $R$ & $\mathrm{R}$ & $\mathrm{R}$ & $R$ & $\mathrm{R}$ & $\mathrm{R}$ & $\mathrm{R}$ & $\mathrm{R}$ & $R$ & $\mathrm{R}$ & $\mathrm{R}$ \\
\hline SMC 04 & $R$ & $R$ & $\mathrm{R}$ & $R$ & $\mathrm{R}$ & $\mathrm{R}$ & $\mathrm{R}$ & $\mathrm{R}$ & $R$ & $R$ & $\mathrm{R}$ & $\mathrm{R}$ & $\mathrm{R}$ & $\mathrm{R}$ & $\mathrm{R}$ & $\mathrm{R}$ & $\mathrm{R}$ \\
\hline SSD 03 & $R$ & $R$ & $\mathrm{R}$ & $R$ & $\mathrm{R}$ & $\mathrm{R}$ & $R$ & $\mathrm{R}$ & $R$ & $R$ & $\mathrm{R}$ & $\mathrm{R}$ & $\mathrm{R}$ & $\mathrm{R}$ & $\mathrm{R}$ & $R$ & $\mathrm{R}$ \\
\hline
\end{tabular}

Keterangan : $R$ : Resisten

Hasil uji sensitivitas (Tabel 5) mengindikasikanbahwa ketigaselektif agensia vibriosis(SMC 01, SMC 04, dan SSD 03) resisten terhadap antibiotikeritromisin, enrofloksasin dan oksitetrasiklin.

Gejala klinis yang ditunjukkan oleh sampel udang vaname (L. vannamei) yang berasal dari tambak intensif Desa Wonorejo, Kabupaten Kendal adalah uropoda berwarna kemerahan, perepoda berwarna kemerahan, pleopoda berwarna kemerahan, antennal scale berwarna kemerahan dan mengalami nekrosis, hepatopankreas berwarna kecoklatan serta melanosis pada abdomen. Austin dan Austin (2007) menjelaskan bahwa gejala klinis yang terdeteksi pada udang sampel tersebut mengindikasikan adanya infeksi bakteri genus vibrio. Gejala klinis yang serupa juga telah dilaporkan pada udang yang terserang vibriosis (Lavilla-Pitogo et al., 2000), Soto-Rodriguez et al., 2010; Sarjito et al., 2012; Huang et al., 2013).

Hasil karakterisasi secara morfologi dan biokimia diperoleh bahwa lima bakteri agensia penyebab vibriosis pada udangvanameyang dibudidayakan secara intensifdari Kabupaten Kendaladalah Vibrio vulnificus (SMC 01), V. mimicus (SMC 04), V.damsella (SSD 01), V. parahaemolytics ( SSD 03) , V. fluvialis (SSD 07).Bakteri Genus Vibrio telah dilaporkan pada beberapa jenisikan/udang air payau (Austin, 2011; Red dan Davar, 2010, Hoel et al., 1998; Randangan et al., 2012). Vibrio vulnificus sering ditemukan pada berbagai ekosistem perairan dan paling banyak ditemukan pada organisme yang hidup di salinitas rendah (Kaysner et al., 1987; Lersen et al.,
1997). Bakteri ini juga telah diketemukan pada ikan kerapu (Sarjito et al., 2007); sea cat fish, Arius felis, (De Paola et al., 1993); udang galah (Mishra et al., 2010), sidat dan rainbow trout (Scharperlaus, 199; Tanrikul ,2007).V. vulnificus, menurut Austin dan Austin (2007) merupakan causative agent vibriosis pada ikan dan udang yang dibudidayakan di air payau dan laut.

V. mimicus bisa diketemukan di lingkungan air tawar dan estuarin, dan merupakan bakteri yang hidup bebas atau berasosiasi dengan zooplankton, crustacea, moluska, penyu, dan ikan (Mizuno et al., 2009). V, mimicus dilaporkan sebagai agensia penyebab vibriosis pada udang windu, P. Monodon, (Srinivasan dan Ramasamy, 2009); lobster, P. Homarus, (Raissy et al., 2011) dan ikan belanak, $M$. Cephalus, (Abdellrazaq dan Khaliel, 2014). $\checkmark$. fluvialis ditemukan menyerang ikan kerapu tikus (C. altivelis) di Lampung dan Situbondo (Desrina et al., 2006), udang windu (P. Monodon) (Srinivasan dan Ramasamy, 2009), ikan kerapu macan (E. fuscoguttatus) di Karamba Jaring Apung Teluk Hurun Lampung (Hastari et al., 2014), ikan belanak (M. cephalus) di Mesir (Abdellrazaq dan Khaliel, 2014).Bakteri V. parahaemolyticus dilaporkan menyerang kegiatan penggemukkan kepiting bakau (S. serrata) di Pemalang (Feriandika et al., 2014), udang windu (P. Monodon) (Felix et al., 2011; Tran et al., 2013; dan Duan et al., 2015), kerang dan tiram di Sao Paulo, Brazil (Rojas et al., 2011), dan udang vaname (L. vannamei) (Tran et al., 2013).

Uji sensitivitas menunjukkan bahwa ketiga selektif agensia penyebab vibriosis 
(SMC 01; SMC 04 dan SSD 03) resisten terhadaperitromisin, enrofloksasin, dan oksitetrasiklin. Hal ini dibuktikan dengan tidak terbentuknya zona bening disekitar kertas cakram pada ketiga bakteri tersebut. Bakteri dikatakan resisten, karena memiliki besaran zona hambat $0-10 \mathrm{~m}$ (NCCLS, 2001). Resisten ini terjadi berkaitan dengan penggunaan antibiotik yang terus menerus dengan dosis yang tidak tepat (Sarjito et al., 2013) dan pemakaian yang meluas dan irrasional (Kemenkes Rl, 2011), serta kandungan antibiotik yang ada di obat tersebut. Sukenda et al. (2008) menjelaskan selain mencemari lingkungan, penggunaan antibiotikyang tidak terkontrol dan secara terus menerus dapat mengakibatkan munculnya strain - strain bakteri resisten (Sukenda, et al., 2008). Menurut Sharma et al., (2009) resistensi dapat terjadi ketika bakteri bermutasi dalam satu atau lain hal, sehingga menyebabkan turun atau hilangnya efektivitas obat, senyawa kimia atau bahan lainnya untuk mencegah atau mengobati infeksi.

Selanjutnya, resistensi pada bakteridapat ditularkan melalui kelompok gen resisten antibotik diantara genes locus yang sama dengan agen seperti plasmid, transposons, dan integrons ke bakteri lainnya (White dan McDermott, 2001). Pada genus Vibrio resistensi dapat ditularkan melalui plasmid dan intergrons serta transport elemen, antara lain SXT (Amita et al., 2003). Oleh karena itu, mekanisme bakteri yang resisten terhadap ketiga antibiotik tersebut juga berkaitan adanya mutasi target antibiotik yang terdapat pada obat atau bakteri memiliki plasmid yang memiliki gen pembawa resisten terhadap antibiotik. Resistensi bakteri dapat terjadi karena mutasi dan seleksi muatan secara acak dan antibiotik berperan sebagai agen seleksi, sehingga dimungkinkan terjadinya multiplikasi kelompok bakteri resisten dan menekan pertumbuhan bakteri yang memiliki sifat sensitif terhadap antibiotik (Atlas, 1995)

\section{KESIMPULAN}

Kesimpulan yang diperoleh dari penelitian ini yaitu gejala klinis tubuh (carapace) memerah, melanosis pada kulit, nekrosis pada ekor, kaki renang dan kaki jalan memerah serta hepatopankreas yang memerah cenderung gelap dari teridentifikasi sebagai Vibrio vulnificus (SMC 01), V. mimicus (SMC 04), V.damsella (SSD 01), V. parahaemolytics ( SSD 03), V. fluvialis (SSD 07). Ketiga selektif agensia penyebab vibriosis yaitu Vibrio vulnificus (SMC 01), $\vee$. mimicus (SMC 04), $\vee$. parahaemolyticsresisten terhadap beberapa obat yang beredar.

\section{UCAPAN TERIMA KASIH}

Terimakasih disampaikan Kepala UPT Laboratorium Terpadu, Universitas Diponegorodan Kepala SKIPM Kelas I, Yogyakarta atas kerjasama dan bantuan fasilitas dalam pelaksanaan penelitian ini. Disampaudang pula terimakasih kepadayang telah membantu sampling dan pelaksanaan penelitian ini.

\section{DAFTAR PUSTAKA}

Amita, S., Chowdhary, R., Tungapathra, M., Ramamurthy, T., Nair, G.B., Ghosh, A., 2003. Class I Integrons and SXT elemen in El Tor strains Isolated before and After 1992 Vibrio cholerae)139 out break Calcuta, India. Emerge. Inf. Dis., 9 : $500-502$

Abdellrazaq, G. S dan S. A. Khaliel. 2014. Molecular Characterization and Antimicrobial Susceptibility of Vibrios Isolated from Healthy and Diseased Avacultured Freshwater Fishes., Global Veterinaria., 13(3): 397-407.

Aguire-Guzman, A; J. G. Sanchez-Martinez; A. I. Campa-Cardova; A. LunaGonzales; F. Ascencio. 2009. Penaeid Shrimp Immune System. Thailand Journal Vetenary Medicine., 39(3): 205215.

Atlas, R. M. 1995. Principles of Microbiology. Mosby-Year Book, Inc., Missouri. 374 pp.

Austin B. dan D.A.Austin. 2007. Bacterial Fish Pathogens. Disease in Farmed and Wild Fish.Fourth edition. Ellis Horword limited, Chichester..

Austin, B. 2011. Taxonomy of Bacterial Fish Pathogens. Austin Veterinary Research $2011,42: 20$ 
Brock, T.D. and M.T. Madigan, 1991. Biology of Microorganisms. Prentice Hall, Englewood Cliffs, New Jersey.

DePaola, A., Gesa M. Capers., Donita Alexander. 1993. Densities of Vibrio vulnificus in The Intestine of Fish from The U.S Gulf Coast. American Society for Microbiology, .7 : $984-988$.

Hasan, N.A; C. J. Grim; B. J. Hley; J. C. M. Alam; E. Taviani; M. Hog; A. C. Munk; E. Saunders; T. S. Brettin; D. C. Bruce; J. F. Challacombe; J. C. Detter; C. S. Han; G. Xie; G. B. Nair; A. Hug; R. R. Colwell. 2010. Comparative Genomics of Clinical and Enviromental Vibrio mimicus. Proc Natl Acad Sci USA, 107(49): $21134-21139$.

Hastari, I. F; Sarjito; S. B. Prayitno. 2014. Karakterisasi Agensia Penyebab Vibriosis dan Gambaran Histologi Ikan Kerapu Macan (Epinephelus fuscoguttatus) dari Karamba Jaring Apung Teluk Hurun Lampung. Journal of Aquaculture Management and Technology., 3(3): 86-94.

Holmstrom, K., 2003. Antibiotic Use in Shrimps Farming and Implications for Enviromental Impacts and Human Health. J Food Sci. And Tech., 38 : 255 262

Holt, J.G., N.R. Kreig, P.H.A. Sneath, J.T. Staley, and S.T. Williams. 1998. Bergey's Manual of Determinative Microbiology. $9^{\text {th }}$ ed. The Williams \& WiLKJTins Co, Baltimore.

Huys, G. 2002. Standard Operating Procedur: Antibiotic Susceptibility Testing of Aquacultur-Associated Bacteria with The Disc Diffusion Meyhod. Laboratory of Microbiology Universiteit Gent, Belgium, 10p.

Irianto, A. 2005. Patologi Ikan Telestoi. Gajah Mada University Press.Yogyakarta.

Jayasree, L; P. Janakiram; R. Madhavi. 2006. Characterization of Vibrio spp. Associated with Diseased Shrimp from Culture Ponds of Andhra Pradesh (India). Journal of The World Aquaculture Society., 37(4): 523-532.

Kamiso H.N., Triyanto dan Sri Hartati. 1994. Karakteristik Aeromonas hydophilapada IkanLele (Clarias sp.)Di
Daerah Istimewa Yogyakarta Dan Jawa Tengah Selatan. Agric. Sci., 4 : 741-750.

Kaysner, C. A., C. J. Abeyta, M. M. Wekell, A. DePaola, R. F. Stott, and J. M. Leitch. 1987. Virulent strains of Vibrio vulnificus isolated from estuaries of the United States west coast. Appl. Environ. Microbiol. 53:1349-1351.

Kementrian Kesehatan Republik Indonesia. 2011. Buku Panduan Hari Kesehatan Sedunia. Kemenkes. Jakarta.

Larsen, J. L., I. Dalsgaard., dan A. Dalsgaard. 1997. Occurence of Vibrio vulnificus Biotype in Danish Marine Environments. American Society for Microbiology. Applied and Environmental Microbiology, .9 :. 7 -13.

Mac Faddin, J. F., 1980. Biochemical Test for Identification of Medical Bacteria, Second Edition. Williams \& Wilkins. Baltimore.

Mishra, P., Samanata, Mohanty, and Maity., 2010. Characterization of Vibrio Species Isolated From Fesh Water Fishesby Ribotypng. Indian J. Microbiol, 50 (1) : $101-103$

National Committee for Clinical Laboratory Standards (NCCLS). 2001. Performance standards for antimicrobial disk susceptibility testing. Approved standard M100-S11. Wayne, Pa: NCCLS.

Nazir, M., 1999. Metode Penelitian. Ghalia Indonesia. Jakarta.

Noorlis, A., Ghazali, F. M., Cheah, Y. K., Tuan Zainazor, T. C., Ponniah, J., Tunung, R., Tang, J. Y. H., Nishibuchi, M., Nakaguchi, Y. and Son, R. 2011. Prevalence and quantification of Vibrio species and Vibrio parahaemolyticus in freshwater fish at hypermarket level. International Food Research Journal, 18: 689-69.

Peggy A. Reed and Ruth Francis-Floyd. 1996. Vibrio Infections of Fish. University of Florida. Florida.

Rad, M. And Davar.S., 2010. Isolation and Characterization of Vibrio (Listonella) anguillarum from Cat fish. J. Vet. Antm. Sci., 34 (4) : $413-415$.

Sarjito, 2010.Aplikasi Biomolekuler Untuk Deteksi Agensia Penyebab Vibriosis Pada Ikan Kerapu danPotensi Bakteri Sponge Sebagai Anti 
Vibriosis.[Disertasi]. Program Pasca Sarjana, Universitas Diponegoro, Semarang.

Sarjito, Ningrum, N.E.W., Radjasa, O.K., dan Prayitno, S.B., 2012. Appication of Repetitive Sequence Base PCR on The Richness of Vibrio on The Tiger Shrimps (Penaeus monodon F.) . Jurnal of Coastal Development, 15 (3) : 304 310

Sarjito, Prayitno, S.B. dan Haditomo, A.H.C. 2013a. Pengantar Parasit dan Penyakit Ikan. UNDIP Press. Semarang.

Sarjito, Prayitno, S.B., Radjasa O.K dan Hutabarat, S. 2007. Causative Agent Vibriosis pada Kerapu Bebek (Cromileptes Altivelis) dari Karimunjawa 1. Pathogenisitasnya terhadap Ikan Kerapu Macan (Epinephelus fuscoguttatus). Jurnal IImu Kelautan, $12(3): 173-180$

Sarjito, Radjasa O.K, Hutabarat, $S$ dan Prayitno S B., 2009. Phylogenetik Diversity of Causative Agent of Vibriosis Associated with Groupers Fish from Karimunjawa Island, Indonesia. Curr. Res. of Microbiol., 2 (1) : 14-21..

Schaperclaus. W., 1992. Fish Disease Vol 1. A.A. Balkema, Rotterdam.

Sharma A. and Chaturvedi, A.N., , 2007. Population dynamic of Vibriosp. in the river Narmahada at Jabalpur. J. Enviroment. Biol., 28 : 747 - 751
Sharma, A., C.R., Bora,C.R., Chaurasia, R.K., and Sahu, V., 2009. Antibiotic Suspectibility and Genetic Analysisi of Vibrio species Isolated from Reverine Enviroent. Curr. Res. Bacteriol., 19: 1 - 13 Smith P, 2006. Break Points for Disc Diffusion Susceptibility Testing of Bacteria Associated with Fish Diseases, A Review Of Current Practice. Aquaculture, 261:1113-1121

Sukenda, L. Jamal,D. Wahyuningrum dan A. Hasan. 2008. Penggunaan Kitosan Untuk Pencegahan Infeksi Aeromonas hydrophila Pada Ikan Lele Dumbo Clarias sp. Jurnal Akuakultur Indonesia, 7(2) : 159-169.

Tanrikul., TT., 2007. Vibriosis an a Epizootic Diseases of Rainbow Trout (Onchorynchuss mykiss) in Turkey. J. Of Bio. Sci., 10(10) : 1733 - 1737

Tatsuya N., Emi I., Nakao N., Nobuhiko N., and Masatoshi M. 2006. Comparison of Vibrio harveyi strains isolatedfromshrimpfarms and fromculture collection intermsof toxicityandantibiotic resistance. Graduate School of Life and Environmental Sciences, University of Tsukuba, Tsukuba, Ibaraki, Japan.

White D.G., and McDermott, P.F., 2001. Biocides, drug resistence and Microbial evolution. Curr. Opin.Microbiol., $4: 313$ $-317$ 